\title{
Filozofia Husserla pożądliwym okiem Krytyczne omówienie książki Dwa ciała Didiera Francka ${ }^{1}$
}

\section{Autor: Didier Franck}

Tytuł: Dwa ciała. Wokół Fenomenologii Husserla Tłumaczenie: Jacek Migasiński i Anastazja Dwulit Wydawnictwo Naukowe Scholar

Rok wydania: 2017

Liczba stron: 220

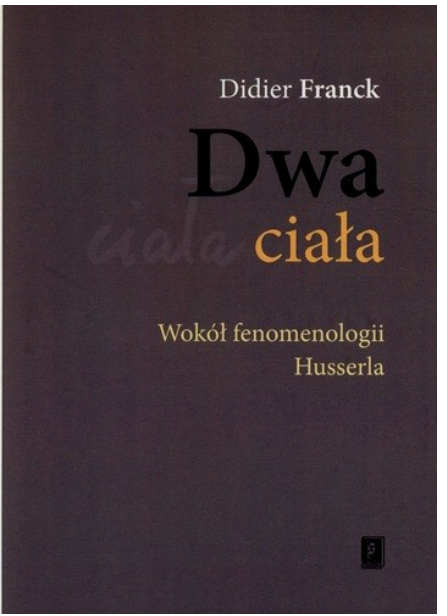

\section{Filip Gołaszewski}

Instytut Filozofii

Uniwersytet Warszawski

philipgolaszewski@gmail.com

Otrzymano 16 sierpnia 2018, zaakceptowano 12 września 2018,

opublikowano zimą 2018/2019.

\begin{abstract}
Abstrakt
Tekst ten stanowi krytyczne omówienie książki „Dwa ciała” Didiera Francka. Zdaniem Filipa Gołaszewskiego, książka ta stara się realizować jedną z jej najpierwotniejszych funkcji, którą jest dialog. Autor udziela własnej odpowiedzi na pytanie, z jakim skutkiem Franck wywiązuje się z tego zadania.
\end{abstract}

Słowa kluczowe: Husserl; Franck; ciało; fenomenologia; intersubiektywność; redukcja.

\footnotetext{
${ }^{1}$ Didier Franck, Dwa ciała. Wokół fenomenologii Husserla, przełożyli Jacek Migasiński i Anastazja Dwulit, Wprowadzenie - J. Migasiński, Wydawnictwo Naukowe Scholar, Warszawa 2017, stron 219.
} 
Jeżeli chcielibyśmy zmierzyć doniosłość czyjejś filozofii liczbą publikacji naukowych, które powstały na jej temat, moglibyśmy założyć, że myśl Edmunda Husserla zmierza na czele pochodu - złożonego nie tylko z filozofów dwudziestowiecznych, lecz także z historycznie największych postaci, jakie wydała ta dziedzina ludzkiej aktywności. Wiele można przytoczyć argumentów na rzecz tego, że nie jest to kryterium słuszne, zaś rolę przypadku w całym tym procesie najlepiej obrazuje historia spuścizny Arystotelesa, której cudowne przetrwanie kresu cywilizacji antycznej zawdzięczamy Arabom. Twórczość Edmunda Husserla sama również stanowi tu przykład dający do myślenia, bowiem z całości jego dorobku ledwie mała część ukazała się za życia autora. Prace, których Husserl nie zdecydował się opublikować, zostały wydane później - i bywa, że dyskutuje się nad nimi tak, jakby stanowiły bezpośrednią kontynuację rozważań ogłoszonych drukiem za życia autora. Teksty te - zredagowane przez osoby, z których większość nie miała nawet sposobności skonsultowania własnego odczytania manuskryptu z zamysłem autora - są dziś niewątpliwie fascynującą lekturą, jednakże ich status w ramach całości filozofii Husserla jest problematyczny. Owe manuskrypty, uratowane $z$ wojennej zawieruchy i dostarczone przez Hermana Van Bredę z Fryburga do Leuven - można rzec, cudownie ocalałe - stanowią dziś dla wielu wykładnię Husserlowskiej fenomenologii. Jednak podobnie jak z dorobkiem Arystotelesa, jest w tym zdarzeniu wiele przypadkowości; wystarczy puścić wodze fantazji, by dostrzec, jak mało brakowało, abyśmy na zawsze utracili ogromną spuściznę Husserla! Jakby tego było mało, losowość zakleszcza się również w samym dziele, nie możemy bowiem rozstrzygnąć, czy jego obecna forma jest zgodna z intencją autora. Pozostają więc tylko domysły - uzewnętrznione w komentarzach, publikacjach i opracowaniach $-\mathrm{z}$ których na własną rękę składamy dziś obraz historycznej doniosłości.

Na gruncie polskim liczba artykułów, monografii i opracowań krytycznych poświęconych Husserlowi jest znaczna ${ }^{2}$. W nieustannie rozrastającym się gąszczu tekstów ${ }^{3}$ pewnego rodzaju lukę stanowią jednak tłumaczenia dzieł bliższych współczesności ${ }^{4}$. Przekład książki Didiera Francka pod tytułem Dwa ciała. Wokót fenomenologii Husserla dobrze ją zaś wypełnia. Oprócz zaspokojenia ciekawości czytelników Husserla pozycja ta może być remedium dla osób spragnionych wiedzy o losach fenomenologii we Francji po roku osiemdziesiątym ubiegłego wieku. Jest również dobrą okazją - o czym więcej za chwilę - do zapoznania się z autorską filozofią Francka.

\footnotetext{
${ }^{2}$ Wgląd w ich przyrost został ułatwiony za sprawą wydawnictwa zatytułowanego Husserl w Polsce. Bibliografia 1895-2010 (Wydawnictwo UŚ, Katowice 2013), z którego możemy się na przykład dowiedzieć, że dwieście sześćdziesiąt jeden prac obejmuje sam okres PRL-owski.

${ }^{3}$ Po roku 1989 aż do dnia dzisiejszego publikacji ukazało się około dwóch razy więcej.

${ }^{4}$ Na przykład spośród prac Dana Zahaviego przetłumaczone są raptem dwie pozycje, a książka autorstwa Nicolasa de Warrena traktująca o czasie w Husserlowskiej fenomenologii nie doczekała się jeszcze przekładu.
} 
Didier Franck nie jest w Polsce szeroko znanym autorem. Dwa ciała to jego pierwsze wielkie dzieło, które zostało przetłumaczone na język polski ${ }^{5}$. We Francji na polu fenomenologii filozof ten uchodzi jednak za postać wybitną, co samo w sobie może już być zachętą do sięgnięcia po omawiany tekst. Niemniej zadanie krytycznego omówienia niesie ze sobą pewne zobowiązanie, któremu łatwo uchybić, poświęcając uwagę samej postaci kosztem utworu - gdy faktycznie powinna ona przemawiać nie mniej i nie bardziej donośnie, niż czyni to jej dzieło.

Zacznijmy więc od przelotnego spojrzenia na Dwa ciała bez wchodzenia w szczegóły w pierwszej chwili jedynie z lotu ptaka. W wydaniu polskim książka Francka składa się z napisanego przez Jacka Migasińskiego wprowadzenia, wstępu autora oraz siedemnastu rozdziałów, w których Franck pieczołowicie analizuje kolejne pojęcia istotne dla myśli Husserla. Osią, wokół której obraca się cała problematyka, jest tytułowa relacja między dwoma ciałami, a właściwie dwoma pojęciami ciała. Są to der Körper z jednej i der Leib z drugiej strony (tłumaczone zgodnie z propozycją Danuty Gierulanki jako „ciało bryła” i ,ciało żywe”). Wychodząc od łączącej je relacji, Franck stara się naświetlić szereg fundamentalnych zagadnień fenomenologicznych, a więc redukcję ejdetyczną, kolejne szczeble konstytucji, ze szczególnym uwzględnieniem kwestii czasu, zagadnienie naukowości, jak i problemy poruszane przez samego Husserla, a więc na przykład tematykę idealizmu i solipsyzmu. Najwięcej uwagi zajmują jednak tematy bezpośrednio związane z cielesnością, czyli podział na sferę obcą i własną, kolejne przemiany owej sfery, proces łączenia w pary i podobieństwa, kinestezy „tutaj” i „tam”.

Ta ostatnia grupa wątków należy w całości do kręgu badań Husserlowskich Medytacji kartezjańskich - i rzeczywiście ów tekst jest podstawowym odniesieniem Francka, co jednak nie znaczy, że ogranicza się do zawartych w nim obserwacji. Wręcz przeciwnie: uzupełnienie wywodu Medytacji kartezjańskich o brakujące wątki to jeden z deklarowanych celów książki Dwa ciała. Wielokrotnie pojawiają się tu odniesienia do innych tekstów Husserla - zarówno tych najwcześniejszych, poprzedzających okres fenomenologiczny (na przykład rozprawa habilitacyjna $O$ pojęciu liczby), jak i manuskryptów ${ }^{6}$.

Medytacje kartezjańskie są zatem w Dwóch ciałach okazją do całościowej interpretacji Husserlowskiej fenomenologii. W ujęciu Francka dwoistość ciała skupia bowiem jak w soczewce fundamentalne napięcia obecne w myśli Husserla, co pozwala krytycznie spojrzeć na jego filozofię. Najistotniejszymi cechami są tu w mojej ocenie uwaga oraz skupienie; i chociaż spojrzenie to zostało wycelowane z określonego dystansu, przemierza różne wątki oraz okalającą je przestrzeń myślową, to jednak wyraziście podkreśla swoistość perspektywy spoglądającego oka. Autor nie ogranicza się do drobiazgowej analizy

\footnotetext{
${ }^{5} \mathrm{~W}$ zbiorze Główne problemy współczesnej fenomenologii (red. naukowa J. Migasiński i M. Pokropski, Wydawnictwo UW, Warszawa 2017) znajduje się jeszcze thumaczenie artykułu Francka Przedmiot fenomenologii z 2001 r. autorstwa J. Migasińskiego.

${ }^{6} \mathrm{~W}$ tym wypadku są to przede wszystkim trzy tomy Zur Phänomenologie der Intersubjektivität.
} 
pojęciowej, która według mnie jest na najwyższym poziomie, lecz bez oporów zaznacza również miejsca charakterystyczne dla własnej optyki. Te elementy pozwalają zaryzykować opinię, że Dwa ciała sytuują Francka w gronie najznamienitszych czytelników Husserla, którzy przy okazji lektury tekstów ojca fenomenologii uczyli się i rozwijali własną filozofię, a więc postaci takich jak Heidegger, Levinas czy Derrida ${ }^{7}$. Filozofowanie, które rozwija siebie w ramach odczytywania cudzego tekstu, wiąże się oczywiście z ryzykiem nadużyć interpretacyjnych, co może być dla niektórych rażące - czytelnik sam musi je podjąć. W stosunku do każdego z wyżej wymienionych filozofów nie brakowało wszak podobnych obiekcji. Franck zdaje się jednak przed tym zagrożeniem umiejętnie bronić, właśnie z uwagi na wspomnianą drobiazgowość analizy. Trudno o jeden cytat, który mógłby szczególnie dobrze zobrazować tę metodę, ponieważ niemal cała książka stanowi tego świadectwo, zaś poszczególne warstwy analizy - podobnie jak u samego Husserla nakładają się jedna na drugą i wzajemnie uzupełniają.

W celu zachowania wierności Husserlowskiej literze omawiany tekst obficie sięga do źródeł. Niemal na każdej ze stron znajdziemy fragmenty prac Husserla, zaś stawiane przez autora tezy są zwykle podpierane kilkoma cytatami. Również z tego powodu język książki jest silnie zabarwiony pojęciowością Husserlowską. Franck nie zakłada krzykliwej maski własnej terminologii, która niedzielnego czytelnika miałaby alarmować z oddali: „Uwaga, głoszę tu własne poglądy!"”. Za tym przemawiają same tezy, a te wraz z odpowiednią dozą uwagi towarzyszącej lekturze powinny być czytelne. Można powiedzieć, że jest to medal Dwóch ciat, który skrzy się na ich piersi. Z dumą pokazuje się zalety, jednak rewers tej odznaki skrywa coś, co może stanowić spory problem dla czytelnika nieobznajomionego z fenomenologią Husserlowską i o czym uprzedzić należy. Jeśli bowiem nie przystępujemy do Dwóch ciał z naręczem własnych medali wyniesionych z lektury pism Husserla, to niewiele będziemy w stanie z książki Francka zrozumieć. Autor nie thumaczy bowiem skomplikowanej pojęciowości fenomenologicznej językiem prostszym. Można z tego czynić zarzut, lecz byłby on chyba niesprawiedliwy. Po pierwsze dlatego, że tego rodzaju objaśnienie nie było zadaniem, które Franck sobie założył. Po drugie zaś - co nawet ważniejsze - paradoksalnie mogłoby to wręcz zaciemnić jeden z celów przyświecających Dwóm ciałom. Tym zaś było ukazanie aporii Husserlowskiej pojęciowości na podstawie samej tej pojęciowości, a nie przy pomocy dokonywanej ad hoc reorientacji pola semantycznego. Franck nie tyle starał się pokazać nową perspektywę fillozoficzną, z punktu widzenia której fenomenologia Husserla poczyniła szereg błędów - co mogłoby przypominać (i niekiedy tak właśnie jest) zabieg iluzjonisty wyciągającego królika z kapelusza - ile próbował, myśląc jak najwierniej wobec samego Husserla, wskazać miejsca,

\footnotetext{
${ }^{7}$ Każdy z nich pojawia się zresztą na kartach książki, ale jedynie pierwszego Franck traktuje jako partnera w rozmowie.

${ }^{8}$ Wyjątkiem są tu niekiedy stosowane pojęcia „,donacji” zamiast „prezentacji” oraz „samo-donacji” w odniesieniu do relacji między cielesnością a oczywistością, jak też rzutowanie tych pojęć na analizy Heideggera. Sam termin został rozpowszechniony przez J.-L.Mariona, który używa go przede wszystkim w kontekście „bycia danym” (niemieckiego die Gegebenheit). Jak podają tłumacze, w przypadku Dwóch ciat „donacja” stosowana jest jako zastępstwo francuskich l'intuition donatrice i la donation.
} 
w których owe błędy mogą się znajdować. Metoda ta rekonstruuje więc znaczenia pojęć Husserlowskich na podstawie wiążących je ze sobą relacji. Przyjrzyjmy się zatem, jakie są najważniejsze tezy wyłożone w książce Dwa ciała.

Ostrze krytycyzmu zostało wymierzone w zagadnienia dotyczące cielesności. Ostatecznie to ich bagatelizacja tłumaczy - w ocenie Francka - szereg aporii występujących na kolejnych szczeblach analiz konstytucyjnych. Nie sposób w tym miejscu wyczerpująco omówić tych wątków, dlatego wspomnę o tych, które w mojej ocenie najlepiej obrazują charakter zarówno przedstawionej w Dwóch ciałach interpretacji, jak i stosowanej przez autora metody. W tym celu muszę jednak sam dokonać skrótów, które mogą być czytelne jedynie dla osób znających tekst Medytacji kartezjańskich.

Na wstępie trzeba więc powiedzieć, że Franck pokazuje komplikacje projektu fenomenologicznego, które występują na kolejnych szczeblach konstytucji fenomenologicznej. Nie ogranicza się jednak do wskazania aporii. Pokazuje, że kolejne etapy nie tylko nie rozjaśniają wcześniejszych problemów, jak można by oczekiwać, lecz także dodatkowo wnoszą kolejne sprzeczności. Analizując na przykład relację ciała żywego oraz sfery tego, co własne, podkreśla, że Husserl nigdy nie sproblematyzował kwestii granic żywej cielesności, chociaż wydaje się ona różna od granic ciała fizycznego. Sam nie próbuje owych granic określić - pyta jednak o ich związek z granicami świata otrzymanego w efekcie redukcji primordialnej i stwierdza, że muszą się one ze sobą pokrywać. Inaczej trudno byłoby zrozumieć sens tego, co znajduje się poza ciałem żywym. Franck zauważa, że te problemy nie pojawiają się w samych Medytacjach kartezjańskich, zaś przelotne uwagi z manuskryptów ukazują jedynie niedostatki fenomenologii, które zostają tu nawet określone mianem „niemożliwości fenomenologii” (Franck, 2017, s. 112).

W tym kontekście Franck zaczyna badać, jak ucieleśnienie w świecie jest możliwe na gruncie opisu fenomenologicznego. Zwraca uwagę na to, że redukcja primordialna rodzi poważne kłopoty, gdy staramy się pojąć takie kategorie jak czas i przestrzeń ${ }^{9}$. Wydaje się, że stoimy przed alternatywą, w której forma czasoprzestrzenna albo jest wspólna wszystkim, albo wcale nie doszło do ukonstytuowania jednorodnej przestrzeni. W tym drugim wypadku nie ma jednak sensu powiedzenie, że przedmiot jest zewnętrzny względem cielesnego ego. Kwestia ta należy do grona problemów, na które Husserl nie odpowiada, jakkolwiek istnieją teksty świadczące o tym, że był go świadom. Kolejny punkt zapalny stanowi pytanie o to, czy konstytucja alter ego nie jest zakładana przez samą siebie (s. 138). To zaś ponownie odsyła do relacji między ciałem żywym a bryłą cielesną. Nieco podobny kłopot rodzi odniesienie pojęcia apercepcji do sfery tego, co własne. Wydaje się bowiem, że w tym kontekście jest to pojęcie wewnętrznie sprzeczne (s. 142).

Niekiedy można odnieść wrażenie, że autor drażni się z Husserlem, na przykład powtarza, że nie ma takiej fenomenologicznej trudności, której nie potrafiłby rozjaśnić opis, i z miejsca demaskuje fałszywość tego poglądu, przytaczając charakterystykę współprezentacji

\footnotetext{
${ }^{9}$ „Albo - to problem jeszcze poważniejszy - co miałaby oznaczać forma czasoprzestrzenna zredukowana do tego, co moje własne?" (Franck, 2017, s. 113).
} 
związanej z der Körper Innego. Następnie stwierdza, że jest to opis dziwny, ponieważ nie wiadomo, w jakim sensie cielesna bryła Innego może być częścią przynależnej mojemu ego przyrody. W innym z kolei miejscu zauważa, że konstytucja źródłowej czasowości odsyła do konstytucji czasowych danych, których nie moglibyśmy uchwycić, jeżeli wpierw nie byłoby ciała żywego. Stwierdza: ,W pewnym sensie Husserl to wiedział, i to od Wykładów z 1905 roku o wewnętrznej świadomości czasu [...]” (s. 55). Podkreśla tu wyrażenia takie jak ,cielesne «teraz» dźwięku” oraz pochodzącą z Doświadczenia i sądu „cielesną teraźniejszość”. Oba zwroty sugerują, że Husserl widział związek ciała z czasem, jakkolwiek nigdy nie przeprowadził ich samodzielnej analizy.

Widzimy zatem, że Franck nie referuje po prostu Husserla, ale stara się dopowiadać do jego rozważań pomysły, które powinny się w nich znaleźć. Można powiedzieć, że $D w a$ ciała to próba zasupłania tych wątków, które pod palcami samego Husserla zdawały się nieustannie rozplatać. Wystarczy jednak spojrzeć na rozmiar dorobku Husserla i objętość książki Francka, aby wysnuć słuszne przypuszczenie, że jest to próba skazana na porażkę. Dla autora Dwóch ciat to jednak nie rozmiar problematyki stanowi w tym przypadku zasadniczą przeszkodę - tą są bowiem ograniczenia samej fenomenologii. Ograniczenia, które nie pozwalają jej ująć żywej cielesności za pomocą swych narzędzi.

Jednym z problemów, na jakie napotyka fenomenologiczne ujęcie żywej cielesności, jest fakt, że Husserl w opublikowanych pracach niewiele uwagi poświęcił analizie przestrzeni - mimo iż ta ma kluczowe znaczenie dla konstytucji innego podmiotu. Ukazują to analizy potencjalności sfery primordialnej (s. 154). Poświadczeniem tych tez są modalności „tutaj” oraz „tam”, rozważane w odniesieniu do der Körper i der Leib. Lokalizacje sfery przeżyć jednoczonych przez czyste ego ugruntowują bowiem wrażenie dotykowe. Trzeba jednak zlokalizować również samo ciało żywe w obrębie świata zawartego w sferze primordialnej. To zaś jest do pewnego stopnia ,nieprzestrzenne”. Franck koryguje opis Husserla, argumentując, że stosowanie określenia „ruch wewnętrzny” jest niewłaściwe z uwagi na to, że „tutaj” ciała własnego jest zawsze absolutnie bliskie sobie, a to wyklucza jakąkolwiek rozpiętość przestrzenną. Ponieważ zaś nie można opisać ruchu bez porównania z innym ruchem - a to wymaga odniesienia do jakiegoś zewnętrza - to w konsekwencji świat sfery tego, co własne, jest światem bez przestrzeni.

Franck wskazuje również na nieprawomocną wieloznaczność w analizie Husserla, która jest stosowana $w$ charakterze argumentu na rzecz tego, iż żywe ciało może za sprawą kinestez zajmować dowolne miejsce w przestrzeni. Miejsce zajmuje jednak wyłącznie ciało fizyczne, a nie der Leib (s. 159). W tym wypadku Husserl używa własnych pojęć nieściśle, co - jak się wydaje - usiłuje zamaskować. Redukcyjne rozdwojenie ego zakłada intersubiektywność, co jest nie do pogodzenia z żonglowaniem modusami „tutaj” i „tam”, które Husserl stosuje w celu ugruntowania możliwości asocjacji. Franck podkreśla tu, że nie wiadomo, jak dochodzi do pobudzenia przez inne die Körper w modus „tam” mojego der Leib na sposób, w którym uświadamiam sobie, że ja mogę być w owym konkretnym 
„tam”. Ponadto moje der Leib może się jawić tylko względem „tutaj”, a więc żeby utrzymać asocjacje, musiałbym jednocześnie być w jakimś „tutaj” i jakimś „tam”: „widząc tu, powinienem być widziany tam, ale jako widzący" (s. 161).

Powyższe analizy naprowadzają na konkluzję, którą Franck sformułował jedynie częściowo. Konstrukcja intersubiektywności na gruncie Medytacji kartezjańskich jest nietrwałą - można rzec, teatralną - fasadą, która po dmuchnięciu rozpada się niby domek z kart. W zgodzie z przedstawionymi przez Husserla analizami pozostaje bowiem jedynie przyjąć, że różne podmioty są identycznymi kopiami transcedentalnego ego, które ulegają pozornemu rozszczepieniu. Niemniej ponieważ każdy z nich jest zasadniczo tożsamy $\mathrm{z}$ ową pierwotną podmiotowością, to do siebie nawzajem mogą się odnosić jedynie w charakterze lustrzanych refleksów. Inny może być dla mnie wyłącznie mną, którym byłbym, gdybym znalazł się w zajmowanym przez niego teraz miejscu. W jakim sensie jest on więc Inny? Tego właśnie pojąć nie sposób, co doskonale obnaża stosunek modalności „tutaj” i „tam”. Ich wymienialność jest możliwa, tylko jeśli przyjąć, że zachodzi w obrębie tego samego podmiotu. Jedynie w obrębie transcedentalnego ego, które samo pozostaje niesprowadzalne do konkretnych der Leib i der Körper, modalność „tutaj” i „tam” może zachowywać się na sposób, do którego Husserl stara się nas przekonać.

Franck konkluduje, że Husserl niedostatecznie przemyślał sprawę podobieństwa w kontekście zagadnień konstytucji intersubiektywności. W manuskryptach zwraca uwagę na konieczność apriorycznego założenia tego samego typu zmysłowego, który warunkuje podobieństwo. Tego założenia nie spełnia jednak odniesienie ciała osoby dorosłej do ciała dziecka, w szczególności zaś bagatelizuje się w ten sposób różnicę płciową. To ostatnie w ocenie Francka najlepiej obnaża niedostatki propozycji opartej na asocjacji. Pięćdziesiąty czwarty paragraf Medytacji pokazuje, że nie można zrozumieć sensu żywego ciała na podstawie ciała fizycznego. W tym wypadku konstytucja Innego nie może w ogóle nastąpić, ponieważ na przykładzie różnicy płciowej widać, że inne der Körper nie może mieć sensu, który posiada moje der Leib (s. 167). Franck podkreśla komplikacje znaczeniowe występujące w relacji między tymi pojęciami. Niekiedy Husserl używa ich jako sobie przeciwstawnych, w innych zaś miejscach - jako synonimów, a to pozwala na zastosowanie wspomnianego już wcześniej przesunięcia znaczeniowego.

Jako że wiele powiedzieliśmy już na rzecz tego, że tekst Francka zasługuje na najwyższą uwagę, zapytać należy o to, czy jest on pozbawiony wad. W kontekście dzieła filozoficznego - a może filozofii jako takiej - pytanie to wydaje się, ogólnie rzecz biorąc, naiwne. W sytuacji, gdy jeden autor interpretuje i komentuje drugiego autora, dochodzi do głosu indywidualność zarówno komentatora, jak i komentowanego. Bez niej interpretacja byłaby zaledwie powtórzeniem czyichś słów, nie miałaby zatem większego sensu. Tam jednak, gdzie autor faktycznie nie ukrywa własnych zapatrywań, nie może być mowy o przemilczeniu spraw, które wydają mu się niezgodne z jego punktem widzenia. W takiej sytuacji interpretacja nie może być pozbawiona krytyki. Książka Francka, podejmująca interpretację filozofii Husserla, wyraziście potwierdza tę regułę, gdyż - jak mówiliśmy - 
sama nie szczędzi jej ciosów. Z kolei niniejsze omówienie, które w tym wypadku należałoby określić mianem interpretacji interpretacji, tym bardziej nie może krytyki przemilczać. Przejdźmy zatem do kilku punktów, które w mojej ocenie mogą nieco ostudzić entuzjazm lektury. W tym celu $\mathrm{z}$ większą uwagą musimy się pochylić nad wybranymi fragmentami książki Dwa ciała.

Zacznijmy od zastrzeżeń wagi lekkiej. W rozdziale zatytułowanym Ciało żywe $i$ ciało bryta $w$ spostrzeżeniu Franck podkreśla, że ,,analiza intencjonalna jest analizą transcendentalnego ego jako tego, które zawiera i konstytuuje wszelką możliwą przedmiotowość" (s. 49). Jej początkiem są Badania logiczne i już tam - na przykładzie analizy spostrzeżenia - zostaje odróżnione mówienie o zanurzonej w świecie psychice od specyficznego rodzaju spostrzeżenia, które od tego związku abstrahuje. Pisząc o tym odrobinę mgliście, Franck zdaje się jednak sugerować, że pozaświatowe nastawienie transcedentalne jest produktem Badań logicznych ${ }^{10}$, faktycznie zaś ten rodzaj optyki przynoszą dopiero Idee. W przypadku osoby zaznajomionej z pismami Husserla nie ma mowy o wprowadzeniu w błąd; inaczej będzie, gdy ktoś zna fenomenologię z drugiej ręki. Można jednak przyjąć, że taka osoba nie jest po prostu adresatem książki Francka.

Teraz należy przejść do kwestii poważniejszych. W moim odczuciu Franck w kilku miejscach wzbrania się przed wyciągnięciem konsekwentnie wniosków z twierdzeń Husserla. Jednym z tego przykładów jest koniec rozdziału trzeciego, dotyczącego intencjonalności, omówionej na przykładzie relacji między ciałem żywym a ciałem bryłą. Franck interesująco zauważa, że warunkiem niektórych przykładów intencjonalności muszą być kinestezy, ponieważ w sytuacji postrzegania to właśnie one odpowiadają na przykład za zmianę perspektywy widzenia. Ciało przemieszcza się w określonym kierunku, a w efekcie również przedmiot oglądany jest pod innym kątem. W dodatku obserwacja ta zostaje poczyniona na własnym przykładzie Husserla dotyczącym sześcianu, co można odczytać jako komentarz mówiący: „No cóż, najwyraźniej Husserl zapomniał jej dodać”. Jednakże po tych obserwacjach zostaje sformułowane następujące spostrzeżenie:

Jeśli ogólnie każdy przedmiot jest strukturalną regułą dla transcedentalnego ego, to świat powinien być dlań regułą uniwersalną. Czy wobec tego fenomenologia nie opiera się przypadkiem na uprzednim kredycie zaufania w jedność świata, czyli ostatecznie na możliwości systemu - kredycie, bez którego byłaby bankrutem? I czy ów kredyt nie należy do porządku faktyczności? Nic bardziej mylnego - skoro Husserl nie robił właściwie nic innego, jak rozwijał czysty sens idei autentycznej i absolutnie ugruntowanej nauki (przyjmowanej jedynie na mocy możliwości), czyli ostatecznie idei owej istotowej korelacji pomiędzy rozumem a rzeczywistością, którą zwie się prawdą. (s. 57)

\footnotetext{
${ }^{10}$ Analiza intencjonalna zostaje bowiem scharakteryzowana za sprawą korelacji noetyczno-noematycznej, bez przywołania omawianej w Badaniach logicznych różnicy między jakością a materią aktu. Następnie zaś padają słowa: „Analiza ta, zapoczątkowana w okresie Badań logicznych i bez przerwy ponawiana, jest odpowiedzią na bardzo gruntowny wymóg. Psychologizm transcedentalny, który fenomenologia chce przekroczyć - a dążenie to jest całym jej przeznaczeniem - ma swe korzenie w określeniu świadomości jako psyche związanej realnie z rzeczywistym światem, to znaczy w koncepcji postrzeżenia, która niewątpliwie nie jest wierna źródłowym i naocznym danym" (Franck, 2017, s. 48-49).
} 
W świetle przytaczanych wcześniej tez czytelnik mógłby tu oczekiwać śmiałego potwierdzenia: owszem, fenomenologia wystawiła weksel na rzecz istnienia przedmiotu, i to już na etapie Badań logicznych, a co więcej nigdy nie udało się jej go spłacić! Świat jest bowiem - zgodnie ze słowami samego Husserla - najogólniejszym sensem przedmiotowości, który zostaje zredukowany i przynajmniej w domyśle pozbawiony istnienia. Franck zapewnia nas jednak o tym, że takie myślenie byłoby błędem, ponieważ Husserla interesował czysty sens idei autentycznej nauki, którą przyjmuje się wyłącznie na mocy możliwości. Jak to się ma do kwestii cielesnych granic fenomenologii, o których będzie dalej mowa? Franck zdaje się nie dostrzegać związku między tymi problemami.

Kolejnym przykładem tego rodzaju zaniedbania jest podejście do kwestii bezzałożeniowości fenomenologicznej. Franck sygnalizuje problem, ale nie podejmuje osobnej analizy. Owszem, kłopoty, jakie niesie w sobie zadanie bezzałożeniowości, zostają przedstawione w kontekście intencjonalnego odniesienia do innego podmiotu, ale sama możliwość opisu bezzałożeniowego nie została zanalizowana pod kątem metodologicznym $^{11}$. Echo tego pominięcia rozchodzi się zaś tam, gdzie Franck pisze o metafizyce do czego jeszcze wrócimy.

Bardzo wiele uwagi zostało tu poświęcone konstytucji alter ego i obiektywnego świata przyrody (s. 192). Na początku przedostatniego rozdziału autor zauważa, że wspólna forma czasowa, która zakłada obiektywną przyrodę, stanowi pochodną konstytucji alter ego - i chociaż w innych miejscach wywodu Husserl zaznacza, że owa forma czasowa nie może poprzedzać tego szczebla konstytucji, to wydaje się, że zdaniem Francka dzieje się dokładnie odwrotnie. W tym wypadku dochodzi do nieuprawnionego zapętlenia etapów konstytucji i trzeba przyjąć, że konstytucja alter ego jest nieosiągalna. Należy tu jednak dodać, że wymaga ona uprzedniego założenia ukonstytuowanej obiektywnej przyrody, w ramach której Inny może występować. Z kolei obiektywna przyroda opiera się na uprzednim założeniu ukonstytuowanego alter ego, które - jak zaznaczyliśmy wyżej samo jest efektem szczebla konstytucji będącego koniecznym a priori jego wystąpienia. To zaś sytuuje nieusuwalną aporię w samym sercu analizy konstytucyjnej. Chociaż Franck wielokrotnie krąży wokół tego spostrzeżenia, to jednak ostatecznie wcale ono nie zostaje sformułowane. Mamy jednak argumentację na rzecz niemożliwości tejże konstytucji na podstawie innych charakterystycznych dla fenomenologii wątków - a więc analizę relacji czasu obiektywnego i czasu świadomości. Z jednej strony, przeskok ten jest konsekwentny - wspomnieliśmy bowiem, że Franck odcina się od krytyki fenomenologicznego dostępu do przedmiotowości. Obiektywna przyroda rozumiana jako jedność świata stanowi zaś wspomniane wcześniej najogólniejsze znaczenie przedmiotowości. W tym wypadku Franck przymyka oko na relację między obiektywnością a intersubiektywnością, ale wykazuje podobną aporię konstytucyjną, obierając czas za punkt odniesienia. Z drugiej strony, wydaje się to jednak o tyle niekonsekwentne, że sama relacja intersubiektywna nie

\footnotetext{
${ }^{11}$ „Podejście fenomenologiczne zawsze i wszędzie aspiruje do tego, by być wolnym od założeń. Nie angażując się w pogłębioną analizę tego wymogu, nie wnikając, czy da się on spełnić i jakie ma granice, ustalmy, jaką przybiera to formę na progu intencjonalnej analizy Innego."
} 
może być pomyślana bez odniesienia do obiektywności przyrody, a w tym przypadku nie wystarcza wspólna forma czasoprzestrzenna. Potrzeba bowiem również tego, co owa forma kształtuje, a więc samej przyrody.

Franck rozpoczyna zatem krytykę Husserlowskiej fenomenologii, ale zatrzymuje się jakby w pół drogi. Jakie mogą być powody takiego zawahania? Między wierszami tej fachowej analizy przebłyskuje nieskrywana sympatia, być może wręcz podziw wobec osoby i dzieła Husserla ${ }^{12}$. Niestosowne byłoby formułowanie tego rodzaju zarzutu - tym bardziej tak wytrawnemu badaczowi - jednak nie można wykluczyć wpływu emocji. Coś takiego może być powodem, dla którego zaczynamy wpisywać w tekst rozwiązania faktycznie w nim niewystępujące, zaś w filozofię wczytujemy sens, który chcielibyśmy znaleźć, zapominając jednak o tym, że niekoniecznie w niej on się znaduje. W przypadku fenomenologii Husserla tego rodzaju dopowiedzenia to stale powtarzająca się historia. Właściwie od samych początków losy przeobrażeń tego nurtu dyktował rytm triumfów kolejnych indywidualności, które zarówno pojęciu, jak i celom oraz metodom fenomenologii nadawały własne znaczenie. Były to zmiany zwykle na tyle odbiegające od ustaleń samego Husserla, że Paul Ricœur mógł później nazwać fenomenologię historią herezji względem filozofii Husserla. O ile jednak zrazu kolejni filozofowie próbowali nadać fenomenologii własny, odrywający od założeń, ustaleń i rozstrzygnięć Husserla sens, o tyle dziś owe starania wydają się przybierać odwrotny kierunek. Kolejne prace za punkt honoru stawiają sobie udowodnienie tego, że wątki charakterystyczne dla późniejszych fenomenologii są już obecne - jeśli nawet nie w pismach, to przynajmniej w intencji Husserla. Ich przeoczenie miało być zaś powodem, dla którego owa filozofia wydawała się niespójna i została niejako porzucona.

Cielesność stanowi tu dobry, ale przecież niejedyny przykład. Niewątpliwie z tą zmianą nastawienia powiązana jest publikacja wcześniej jedynie wybiórczo dostępnych manuskryptów. Pisma te odsłaniają ogrom tematyki pozostającej w kręgu zainteresowań fenomenologii Husserlowskiej, których nie udało się wcielić w kolejne propozycje systematycznego programu filozofii. W tym wypadku ciężar powiązania owych zagadnień spoczywa na barkach współczesnych komentatorów. Czasem można odnieść wrażenie, że zamiast propozycji rozjaśniających kwestie teoretyczne mamy do czynienia z powoływaniem się na słowa samego mistrza, które przypieczętowują wątpliwości, dźwięcząc równie dobitnie, jak pięść uderzająca w stół. Jednakże Dwa ciała wskazują raczej niedostatki takiego schematu ${ }^{13}$. Dlaczego zatem autor wstrzymuje się przed wyciągnięciem ostatecznych konsekwencji z własnej analizy? Mogę jedynie powtórzyć sformułowaną wcześniej

\footnotetext{
${ }^{12} \mathrm{Na}$ temat pasywnej genezy Franck pisze na przykład: „Husserl poświęcił temu zwykłemu naocznemu ujęciu przepiękną analizę, która pomaga nam odróżnić wiele sensów pasywności i rozpoznać w biernej konstytucji czasowości wstępny warunek wszelkiej przedmiotowej konstytucji” (s. 84). Ostatni rozdział kończy zaś uwaga na temat przedśmiertnych słów Husserla skierowanych do żony. Słów, w których dla Francka zdaje się pobrzmiewać echo tajemnicy fenomenologii.

${ }^{13}$ Kilka przykładów już padło, ale można przytoczyć kolejny. Gdy Franck objaśnia związek redukcji ejdetycznej z zagadnieniem ,pra-faktyczności”, zmuszony jest sięgnąć do uwag zawartych w Husserlianach nr 15, w których
} 
sugestię bez możliwości rozstrzygnięcia o jej trafności. Znajdując się jednak pod głębokim wrażeniem uważności analizy Francka, nie widzę innego wyjaśnienia dla zawartych w niej niedopowiedzeń. Te bowiem zbyt jaskrawo kłócą się z przyjętą przez autora metodą interpretacji i - co więcej - mogą rzutować na zaproponowane przez niego rozwiązania. Aby powiedzieć o tych ostatnich, potrzebnych jest kilka słów o relacji między czasem a przestrzenią oraz o kończących dzieło rozdziałach.

W analogii do źródłowego sensu obiektu czasowego, którego nie powinniśmy nazywać świadomością, Franck mówi o źródłowym rozumieniu fenomenu przestrzennego właściwego ciału w jego relacji do absolutnego „tutaj”. To przykład kolejnego ujęcia, którego brakuje w analizie samego Husserla. Franck zwraca uwagę na to, że w przypadku czasu fenomenologia dochodzi tu do muru, którego przekroczyć nie potrafi. W Wykładach z fenomenologii wewnętrznej świadomości czasu zostaje to nazwane absolutną subiektywnością, której wyjaśnić nie sposób (Husserl, 1989, s. 110) Prawomocnie możemy jednie powiedzieć, że świadomość jest czasem, ale właściwe znaczenie tezy pozostaje tajemnicą, ponieważ w takim wypadku czas musiałby wyprzedzać samą analizę konstytucyjną a zgodnie z jej założeniami nie może tego zrobić. Franck zauważa, że podobna zależność zachodzi w przypadku relacji ciała i przestrzeni, co wydaje się obserwacją nie tylko bardzo interesującą, lecz także obnażającą granice fenomenologii w kontekście drugiej obok czasu fundamentalnej kategorii filozoficznej.

Jednak to fenomenologia czasu odgrywa w dziele Francka kluczową rolę. Ostatnie dwa rozdziały są próbą ustalenia granic metody fenomenologicznej na przykładzie relacji między ciałem żywym a czasem. W tym wypadku nie powinien być zaskoczeniem fakt, iż autor podejmuje analizę Wykładów z fenomenologii wewnętrznej świadomości czasu. Najważniejsza trudność, którą wskazuje za Husserlem, dotyczy zapętlenia dwóch czasowych strumieni: jednego, w którym dochodzi do ukonstytuowania czasowej danej (hyle), oraz drugiego, którym jest sam obszar ego. Konstytucja strumienia pierwszego opiera się na drugim za sprawą niekończących się powtórzeń. W tym miejscu analiza dotyka chyba jedynego punktu, przed którym sam Husserl otwarcie skapitulował, mówiąc: „Dla tego wszystkiego brak nam słów" (Husserl, 1989, s. 111). Franck nie stara się rozstrzygnąć samej tej aporii. Proponuje jednak, aby myślenie o niej rozpocząć od związku czasu z der Leib, ponieważ to właśnie on umożliwia świadomości odniesienie do przepływu hyletycznego. Ponadto ciało żywe musi wyprzedzać samą czasowość, ponieważ ta zostaje dopiero ukonstytuowana w strumieniu hyletycznym. Franck podkreśla też, że owa uprzedniość der Leib nie uszła uwadze Husserla, czego przykładami są fragmenty Zur Phänomenologie der Intersubjektivität oraz fragment manuskryptu C6. Zdaniem Francka Husserl widział, że konstytucja teraźniejszości związana jest z der Leib za sprawą popędu czy też swego rodzaju intencjonalności popędowej. W odniesieniu do przytoczonych fragmentów trudno jednak powiedzieć, jak sam Husserl ten rodzaj intencjonalności rozumiał. Dla Francka

Husserl podkreśla, że pomyślenie eidos ego transcedentalnego jest niemożliwe bez transcedentalnego ego faktycznego, a to odsyła do zagadnienia absolutu. Franck podkreśla jednak, że te niezbędne do nadania fenomenologii spójności kwestie są właściwie nieobecne w Medytacjach kartezjańskich. 
wydaje się on zaś przyczynkiem do zrównania fenomenologii z psychologią - $\mathrm{i}$ tu pojawia się kolejny niepokojący wątek całej tej analizy. Jedna z kończących rozdział piętnasty obserwacji jest następująca:

Źródłem transcendencji jest pieszczota, ale obracając się bezpośrednio w szok, jest zarazem tej pieszczoty redukcją. Czy nie uzyskujemy tym samym narzędzia, by uchwycić, dlaczego źródło świata tkwi w pewnym sensie w świecie, dlaczego psychologia pokrywa się z fenomenologią? (Franck, 2017, s. 190)

W konfrontacji z tak sformułowanym przypuszczeniem każdemu fenomenologowi zapali się co najmniej lampka alarmowa z tyłu głowy. Jeśli dążymy do utożsamienia ze sobą psychologii i fenomenologii, to jesteśmy oczywiście nakierowani na zupełnie inny cel niż ten przyświecający Husserlowi. W gruncie rzeczy zmierzamy w kierunku zaprzepaszczenia tego rozróżnienia, którego redukcja miała być ostatecznym ugruntowaniem. To jednak wydaje się celem Francka, który groźbę psychologizmu najwyraźniej sprowadza do wystąpienia empirii w opisie fenomenologicznym. Trzeba tu wiec przypomnieć, że dla samego Husserla początkową stawką była autonomia logiki, którą ugruntowywała idealność znaczenia. Wydaje się, że radykalnego odcięcia od empirii - wprowadzonego do fenomenologii wraz z aktem redukcji - nie trzeba z konieczności odczytywać jako argumentu przeciwko psychologizmowi. Z uwagi na sztuczność redukcji byłby to raczej argument mało przekonujący. Jeżeli zaś spojrzymy na redukcję jako na zabieg normatywny, który wyznacza przede wszystkim ramy metodologiczne, to relacja między psychologizmem a ucieleśnioną świadomością nie jest tak bezpośrednia, jak opisuje ją Franck. Oczywiście samo z siebie nie czyni to związku świadomości ze światem bezproblematycznym, jak i nie usuwa z aktu redukcji jego zasadniczych sprzeczności. Chciałbym jednak podkreślić, że samo uznanie ciała żywego za przedfenomenologiczne i nieredukowalne nie sprawia jak za dotknięciem magicznej różdżki, że fenomenologia staje się psychologią. Tak samo wykazanie nieredukowalności języka nie sprawi, że fenomenologia z miejsca przekształci się w językoznawstwo lub semiotykę. Kwestia ewentualnego oddziaływania cielesności na idealność znaczeń wydaje się dla fenomenologii Husserla problemem interesującym jednak niepostawionym w tej formie przez Francka. Prawdopodobnie dzieje się tak z tego względu, że gdy tylko pojawia się kwestia języka oraz znaczenia, Franck pośpiesznie odwraca głowę w przeciwną stronę.

Jest to wątek, który został tu wręcz zdumiewająco ostentacyjnie zbagatelizowany. Omawiając problematykę epoché, autor zauważa wprawdzie, że jest ona wykluczeniem możliwości mówienia w liczbie mnogiej, które zawsze zakłada intersubiektywność. Jednak uznaje też, że nie jest to kłopot, ponieważ w fenomenologii warstwa językowa zwyczajnie nigdy nie była uważana za źródłową, a do tego ujmowanie wyrażenia w postaci czystej wymaga wykluczenia odniesienia do innego podmiotu. To intrygujące, że przy tym stopniu uwagi, który Franck poświęca Medytacjom kartezjańskim, uznaje jednocześnie sprawę języka za tak nieistotną. Pozostając w zgodzie z własną metodą analizy, powinien wszak zauważyć, że niecałe trzy strony po tym, jak Husserl - wskazując na konieczność rozpoczęcia analizy od transcendentalnej subiektywności - kategorycznie podkreśla: ,[...] prawidłowo recz ujmując, nie powinniśmy komunikować już odtąd niczego w pierwszej 
osobie liczby mnogiej” (Husserl, 2009), następnie bez słowa komentarza powraca do stosowania tych nieuprawnionych zaimków. Tego przeoczenia ze strony Francka należy żałować przede wszystkim dlatego, że interpretacja korygująca Husserla, ale pomijająca kwestie znaczeń, po prostu nie może być kompletna. W tym kontekście nie dziwi fakt, iż proponowana na koniec wizja intersubiektywności pozostaje równie tajemnicza, co zapewnienia Husserla o fenomenologicznym odparciu solipsyzmu. Gdyby tylko zwrócić uwagę na coś więcej niż sam związek czasu z ciałem - a więc na ich wspólną relację wobec znaczenia - otwarłyby się zupełnie nowe horyzonty badawcze. Pozwoliłyby one może - w tym miejscu sam dam się porwać spekulacji - na przekroczenie tradycyjnej dychotomii między czuciem a myśleniem, która zdaje się dziś rzutować na relację między pojęciem, emocją a znaczeniem.

Franck stara się rozwikłać fundamentalną aporię czasu fenomenologicznego poprzez uznanie transcedentalnej subiektywności za de facto intersubiektywność. Wydaje się, że taka sytuacja faktycznie rozwiązywałaby gros problemów fenomenologii Husserlowskiej. Jednocześnie zbliżałaby filozofię Husserla do wcześniejszych nowożytnych koncepcji, na przykład takich jak Heglowskie rozumienie intersubiektywności ${ }^{14}$. To jednak nie jest możliwe - jak zauważa sam Franck - o ile nie usuniemy z fenomenologii ,zasady zamknięcia ego". Dlaczego autor wzbrania się przed tym, by powiedzieć, że nie jest to możliwe wraz z postulatem redukcji? I tym samym nie jest możliwe tak długo, jak fenomenologia chce pozostać fenomenologią ${ }^{15} \ldots$ Trudno mi znaleźć odpowiedź na to pytanie. Już od pierwszych rozdziałów bowiem można odnieść wrażenie, że przymyka się tu oko na problematyczność metody redukcyjnej. Zgodnie z wcześniejszą sugestią powinniśmy stwierdzić, że Franck nie chce w punkcie wyjścia przekreślać całej koncepcji Husserla - po to, aby na tyle, na ile możliwe jest podążanie za jego sposobem myślenia, wykazać tegoż wewnętrzne aporie. Takie podejście jest niewątpliwie uczciwe - cóż to bowiem za dokonanie: przypisać sobie zwycięstwo nad kimś grającym w szachy, gdy sami używamy figur tak, jakby to były warcaby? W moim odczuciu to założenie przyświeca większości rozdziałów. Gdy jednak czytamy kończące dzieło analizy dotyczące czasowości, możemy odnieść wrażenie, że właściwa stawka rozgrywki była inna. Być może Franck chciał przede wszystkim utorować drogę do Heideggerowskiego ujęcia analityki egzystencjalnej jako hermeneutyki faktyczności w łonie Husserlowskiej fenomenologii, co kwestię samej fenomenologii - jej metody, zadań i celów - spycha na dalszy plan. Zaznacza on jednak

\footnotetext{
${ }^{14} \mathrm{~W}$ tym kontekście należy koniecznie wspomnieć o tym, że Franck jako jeden z niewielu czytelników Husserla podkreśla bliskość fenomenologii z filozofią Hegla. Dostrzega ją na przykładzie Husserlowskiego pojmowania idealizmu (rozdział szósty).

${ }^{15}$ Przynajmniej w pierwotnym Husserlowskim rozumieniu fenomenologii, w którym redukcja decyduje o jej „być albo nie być”.
} 
krytyczny dystans wobec propozycji Heideggera. Podkreśla, że Dasein jest przez czasowość ,zdominowane”, natomiast ciała żywego nie możemy do czasu zredukować, ponieważ to ono „daje nam czas"16.

Ostatecznie analityka ciała żywego rozstrzyga w opinii Francka nie tylko o sensie fenomenologii, lecz także o istocie całej współczesnej metafizyki. W zestawieniu z resztą książki te ostatnie uwagi oparte są na rażących skrótach myślowych, które nie pozwalają dokładnie stwierdzić, jaka relacja wiąże der Leib z metafizyką i filozofią Heideggera poza związkiem ad hoc zasugerowanym czytelnikom przez autora. Franck wspomina o skoku od filozofii do myślenia oraz od myślenia do filozofii, który jest narażony na niedostateczne zrozumienie. Na próżno szukalibyśmy tu jednak problematyzacji pojęcia filozofii lub myślenia, nie mówiąc już o tym rodzaju uwagi, z jaką Franck podchodził do Husserlowskich terminów i aporii. Z jednej strony, w świetle całego dzieła nie jest to kwestia pierwszej wagi, ponieważ nie narusza jego zasadniczej logiki i nie ujmuje wartości przeprowadzonym analizom. $\mathrm{Z}$ drugiej jednak strony, gdy tego rodzaju tezy padają, całkowicie uprawnione wydaje się oczekiwanie argumentacji - zwłaszcza w epoce, której stosunek do metafizyki jest na tyle krytyczny i zniuansowany, że trudno byłoby zliczyć wszystkie obwieszczenia o kresie metafizyki i filozofii, z których jednak chyba żadne na dobre nie odwiodło zainteresowanych od filozofowania.

W tym kontekście również wstęp książki nie pozostaje wolny od podobnych mankamentów. Autor bowiem nie szczędzi czytelnikom konstatacji o śmierci filozofii, która jest zarazem początkiem myślenia, aby następnie na bez mała dwustu stronach zajmować się uprawianiem tego, co dziś zwykle uznajemy za filozofię ${ }^{17}$. Gdy zaś wrócimy do wstępu już po lekturze całości, być może inaczej odczytamy zdanie: „Innymi słowy, im lepiej będziemy czytali Husserla, tym lepiej będziemy mogli ocenić Heideggera" (s. 17). Skoro bowiem porażka fenomenologii stanowi zarazem koniec filozofii, jak i początek myślenia, to czy stawką tego drugiego ${ }^{18}$ powinna być możliwość dobrej oceny Heideggera? Zaryzykuję twierdzenie, że jest wielu filozofów, którzy z uwagą czytali i głęboko sobie cenią filozofię Heideggera, a jednak będą jak najdalsi od uznania jej oceny za jedno z kluczowych zadań stojących przed myśleniem.

\footnotetext{
${ }^{16}$ „Żywe ciało konstytuuje czas, ale skoro każde ciało żywe odsyła do innego ciała żywego - oznacza to, że różnica cielesna i relacja międzycielesna uczasawiają czas" (s. 211). W tym kontekście warto też wspomnieć o interpretacji fenomenologicznej relacji między cielesnością a czasem w wydaniu Marka Pokropskiego, który nie tylko wydaje się zgadzać z Franckiem co do uprzedniości der Leib względem czasu, lecz także krytycznie odnosząc się do Husserlowskiej postaci redukcji, proponuje własną modyfikację, którą jest redukcja do działania. Zob. Pokropski, 2013.

${ }^{17}$ Jeżeli chcielibyśmy bronić autora, stwierdzając, że ten paradoks zauważa, to owszem, zauważa - jednak co z tego? Być może chodzi o zasadność pisania o tym, co czyni filozofię filozofią, zamiast interpretacji problemów, które a priori uznajemy za filozoficzne.

${ }^{18}$ Ponieważ sam autor nie klaruje różnicy między pojęciami filozofii i myślenia, to na własną rękę nie będę tego wysiłku tu podejmował.
} 
Ten lekki stosunek do metafizyki widać również tam, gdzie Franck powtarza za Husserlem przekonanie o neutralności metafizycznej Badań logicznych, nie tłumacząc jednak, na czym ona polega (s. 16). Trafnie obrazuje to wyrażony wcześniej pogląd, że w Dwóch ciałach niektóre z deklaracji Husserla zostały przyjęte za dobrą monetę. Książka, której główną tezą jest konieczność analizowania cielesności z uwagi na granice metafizyki, bez wątpienia powinna obydwu zagadnieniom poświęcić równie wiele uwagi. Cielesność gra tu jednak pierwsze skrzypce, zaś metafizyka potraktowana zostaje przyczynkarsko. Wejście w tego rodzaju polemikę wymagałoby zdecydowanie więcej, niż jesteśmy w stanie osiągnąć w ramach tego omówienia, dlatego tylko na próbę postawię tu hipotezę, że żadna filozofia nie jest bardziej związana i zależna od metafizyki niż ta, która w punkcie wyjścia deklaruje się od niej odciąć. O tym, że Badania logiczne, jak i cała fenomenologia nie są w tym przypadku wyjątkiem, najlepiej świadczy jej wypreparowany teoretyczny stosunek do przedmiotu i świata jako całości. Początkowo jedynie postulowany, ostatecznie wydaje się Husserlowi osiągalny wyłącznie za sprawą w praktyce niewykonalnego zabiegu redukcji. Paradoksalnie to właśnie redukcja - a dokładnie jej niemożliwość - ukazuje najlepiej metafizyczność fenomenologii. Bezzałożeniowy opis fenomenologiczny jest de facto możliwy tylko przy założeniu ontologii separującej transcedentalne ego od świata, co dla istoty ludzkiej może posiadać sens wyłącznie normatywny ${ }^{19}$. Trudno mi sobie wyobrazić tezę bardziej metafizyczną, niezależnie od ciągłych zapewnień o neutralności tego zabiegu wygłaszanych przez samego Husserla.

Na koniec należy przedstawić kilka uwag na temat samego wydania i przekładu. Zasadniczy tekst poprzedza trzystronicowe wprowadzenie autorstwa Jacka Migasińskiego, które wdraża nas w poruszaną na kartach dzieła problematykę, naświetlając jej najważniejsze problemy. Na końcu znajduje się indeks nazwisk - bez wątpienia pomocny, chociaż w ramach samego wywodu cudze interpretacje Husserla pełnią tu głównie funkcję uzupełnień. Wyjątkiem, który już został wcześniej podkreślony, jest postać Heideggera. Brak niestety indeksu pojęć, co z wydawniczego punktu widzenia stanowi mankament - nad którym rozwodzić się jednak nie warto.

Wspomniałem już o elitarności analiz prowadzonych przez Francka; odłożywszy jednak ten wątek na bok, można powiedzieć, że Dwa ciała czyta się wyśmienicie. Nie znając francuskiego, ocenić mogę wyłącznie język przekładu - i w tym wypadku chciałbym podkreślić zasługę tłumaczy. Pozostaje on bowiem tak klarowny, jak tylko na to pozwala pojęciowość fenomenologiczna. Został też uzgodniony z kanonem obowiązującym w polskich tłumaczeniach Husserla. Lektura wymaga ciągłej uwagi, ale tej nie podyktowała zawiłość stylu czy zdań - źródłem tego stanu rzeczy jest sama podjęta problematyka. Język pozostaje zatem niewątpliwym sprzymierzeńcem czytelnika w ramach toczonej z tekstem potyczki; nie stara się onieśmielić finezją i ekstrawagancją, które w przypadku niektórych autorów maskują brak treści. W moim odczuciu zostały tu przyłożone dokładnie takie środki, jakie są potrzebne do wyrażenia postulowanych znaczeń. Tam, gdzie

\footnotetext{
${ }^{19}$ Chcąc zaś dostosować się do tego rodzaju normy, pozostawałoby jedynie milczeć, ale i to nie byłoby przecież zabiegiem absolutnie pozbawionym założeń.
} 
chodzi o komunikowanie sensu, jest on pogłębiany za pomocą wskazania na związki łączące ze sobą poszczególne pojęcia, co pozwala czytelnikowi na konfrontację z własnymi założeniami dotyczącymi Medytacji kartezjańskich oraz na ich ewentualną rewizję przeprowadzoną w świetle przedstawionych objaśnień.

Niekiedy Franck ucieka w kierunku metafory, na przykład gdy w kontekście zaproponowanego odwrócenia Husserlowskiej relacji między der Leib a der Körper mówi o „rozpuszczeniu zewnętrzności i transcendencji” (s. 190). Powołując się na Bergsona, autor stwierdza: „Moje ciało, narząd całej percepcji, ośrodek i środek każdego spostrzeżenia, rozciąga się tak daleko, jak moja percepcja - sięga gwiazd” (s. 112). Tego rodzaju fragmentów jest jednak stosunkowo mało, co uprzedzonych do tej formy wyrazu powinno zachęcić, chociaż jej zwolennicy mogą to odebrać za przejaw umiarkowanego polotu językowego. Niemniej w moim odczuciu przed takim zarzutem autor broni się doskonale, o ile tylko z założenia nie redukujemy dobrego stylu do bogactwa stylistyki. Tej bowiem nie uświadczymy, ale w zamian mamy język przejrzysty i treściwy. Niejakim wyjątkiem są tu wstęp oraz ostatnie rozdziały książki, a więc miejsca, w których Franck stara się pokazać powiązanie der Leib i czasu ${ }^{20}$. Emocje wyrażone są równie klarownie, zachwyt jest zachwytem, a wątpliwość - stawianym wprost pytaniem.

Wszystko to ukazuje, że zarówno autorowi, jak i tłumaczom w pierwszym rzędzie chodziło o czytelnika. To zaś pozwala stwierdzić, że Dwa ciała są książką uczciwą, co na tle różnych analiz filozofii Husserla nie jest wcale regułą. Szacunek dla czytelnika pokazuje jeszcze więcej: Dwa ciała to dzieło, które tak naprawdę nie ma charakterystycznych dla filozofii - zarówno dwudziestowiecznej, jak i współczesnej - problemów z tożsamością. Stara się bowiem realizować jedną z jej najpierwotniejszych funkcji, którą jest dialog. Odpowiedź na pytanie o to, czy robi to dobrze, pozostaje jednak w gestii każdego z czytelników z osobna. Własnej udzieliłem zaś tutaj i na tym godzi się zakończyć.

\footnotetext{
${ }^{20}$ Do pewnego stopnia trudność tlumaczy samo zagadnienie. Gdy usiłujemy sięgnąć do czegoś przedczasowego, musimy dokonać gwałtu na własnych środkach wyrazu, a więc na języku - którego przecież bez czasu ani nie sposób używać, ani nie wiadomo, jak o nim myśleć. $Z$ tym problemem bezustannie zmagał się Heidegger, zaś w przypadku Husserla wyznaczył on właściwie granice analizy fenomenologicznej. Franck zwraca uwagę na tę drugą kwestię, ale - jak sam wielokrotnie pokazuje na przykładzie Husserla - świadomość problemu nie oznacza jego rozwiązania. Na poziomie językowym mamy więc do czynienia z kalką Heideggerowskich propozycji; Franck twierdzi na przykład, że relacja cielesna ,uczasawia czas”.
} 


\title{
Bibliografia
}

Franck, D. (2017). Dwa ciała. Wokót fenomenologii Husserla. (J. Migasiński, A. Dwulit, thum.). Warszawa: Wydawnictwo Naukowe Scholar.

Heidegger, M. (2008), Bycie i czas. (B. Baran, tłum.). Warszawa: Wydawnictwo Naukowe PWN.

Heidegger, M. (2009). Podstawowe problemy fenomenologii. (B. Baran, thum.). Warszawa: Fundacja Aletheia.

Husserl, E. (2006). Badania logiczne, t. 1-2. (J. Sidorek, thum.). Warszawa: Wydawnictwo Naukowe PWN.

Husserl, E. (2013). Doświadczenie i sąd. (B. Baran, thum.). Warszawa: Fundacja Aletheia.

Husserl, E. (1992). Filozofia jako ścista nauka. (W. Galewicz, thum.). Warszawa: Fundacja Aletheia.

Husserl, E. (1975-1974). Idee czystej fenomenologii i fenomenologicznej filozofii, t.1-2, (D. Gierulanka, tłum.). Warszawa: Państwowe Wydawnictwo Naukowe.

Husserl, E. (1985). Intersubiektywność a podmiotowość transcendentalna. (B. Baran, thum.). W: Twarz Innego (Teksty filozoficzne). Kraków: PAT.

Husserl, E. (1993). Kryzys europejskiego czlowieczeństwa a filozofia. (J. Sidorek, thum.). Warszawa: Fundacja Aletheia.

Husserl, E. (1987). Kryzys nauk europejskich i fenomenologia transcedentalna. (S. Walczewska, thum.). Kraków: PAT.

Husserl, E. (2011). Logika formalna i logika transcedentalna. (G. Sowiński, tłum.). Warszawa: Wydawnictwo IFiS PAN.

Husserl, E. (2009). Medytacje Kartezjańskie. (A. Wajs, thum.). Warszawa: Wydawnictwo IFiS PAN.

Husserl, E. (1991). O pochodzeniu geometrii (Z. Krasnodębski, thum.). W: J. Rolewski, S. Czerniak (red.), Wokót fundamentalizmu epistemologicznego. Warszawa: IFiS PAN.

Husserl, E. (1989). Wyklady z fenomenologii wewnętrznej świadomości czasu. (J. Sidorek, thum.). Warszawa: Państwowe Wydawnictwo Naukowe.

Pokropski, M. (2013). Cielesna geneza czasu i przestrzeni. Warszawa: Wydawnictwo Instytutu Filozofii i Socjologii PAN.

\section{Lusty Glance at Husserl's Philosophy: \\ A Critical Discussion of the Book Flesh and Body by Didier Franck}

\begin{abstract}
This text is a critical discussion of Didier Franck's book Flesh and Body: On the Phenomenology of Husserl. According to Filip Gołaszewski, this book tries to realize one of its most-primary functions, which is dialogue. The author gives his own answer to the question with what effect Franc fulfills this task.
\end{abstract}

Keywords: Husserl; Franck; flesh; body; phenomenology; intersubjectivity; reduction. 